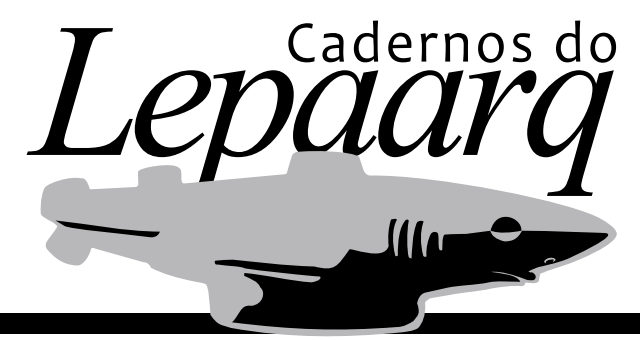

\title{
CULTURAL HERITAGE BUILDING UP FUTURE THINKING
}

PATRIMÔNIO CULTURAL CONSTRUINDO PENSAMENTO FUTURO

Cornelius Holtorf

Tiago Silva Alves Muniz

Como citar este artigo:

HOLTORF, Cornelius; MUNIZ, Tiago Silva Alves. Cultural heritage building up future thinking. Cadernos do Lepaarq, v. XVII, n.34, p. 337-344, Jul-Dez. 2020. 


\title{
Cultural heritage building up future thinking
}

\author{
Cornelius Holtorf ${ }^{\text {a }}$
}

Tiago Silva Alves Muniz ${ }^{\mathrm{b}}$

\begin{abstract}
Resumo:
Qual é o papel do patrimônio cultural na construção de futuros? Como a cátedra da Unesco pode fornecer ferramentas para pensar e fazer futuros criativos? E como a arqueologia se relaciona com isso? Esta entrevista desenvolve o conceito de patrimônios futuros e chama a atenção do "setor do patrimônio" para ampliar a interdisciplinaridade e o engajamento de colaborações de mente aberta com parceiros fora da academia e da indústria, por exemplo. Aqui, Dr. Cornelius Holtorf, arqueólogo, Professor de Arqueologia na Linnaeus University, Diretor da Escola de Pós-Graduação em Arqueologia de Contrato (GRASCA) e Cátedra Unesco em Patrimônios Futuros na Linnaeus University, fala sobre seus projetos / ideias em andamento e comentários sobre o impacto do turismo e covid-19 ao patrimônio cultural, futuro do patrimônio e alfabetização em futuro.
\end{abstract}

\section{Palavras-chave:}

patrimônios futuros, criador de futuro, preparação para um futuro global, patrimônio arqueológico, teoria e método em arqueologia.

\begin{abstract}
:
What is the role of cultural heritage in constructing futures? How can a UNESCO Chair provide tools for creative futures thinking and future-making? And how does archaeology relate to that? This interview develops the concept of heritage futures and calls the attention of the "heritage sector" to broad interdisciplinarity and open-minded collaborations with partners outside of academia and industry, among others. Here, Dr. Cornelius Holtorf, archaeologist, Professor of Archaeology, Director of the Graduate School in Contract Archaeology (GRASCA) and UNESCO Chair on Heritage Futures at Linnaeus University talks about his ongoing projects/ideas and comments on the impact of tourism and covid-19 on cultural heritage, heritage futures and future literacy.
\end{abstract}

\section{Keywords:}

heritage futures, future-making, preparedness for a global future, archaeological heritage, theory and method in archaeology

\footnotetext{
a Arqueólogo, Professor de Arqueolgia na Linnaeus University, Diretor da Escola de Pós-graduação em Arqueologia de Contrato (GRASCA) e Cátedra da Unesco em Patrimônios Futuros. cornelius.holtorf@lnu.se

${ }^{\mathrm{b}}$ Arqueólogo, Pesquisador visitante no Departamento de Ciências Culturais, Linnaeus University, Suécia; Doutorando em Antropologia (Arqueologia) na Universidade Federal do Pará. Email: tiago.samuniz@gmail.com
} 
TM: Firstly, let me thank you for joining this conversation. I would like to begin talking about the Heritage Futures Project. Can you talk about how the concept of 'Heritage Futures' was created and linked to a Unesco Chair?

$\mathrm{CH}:$ In 2012, Anders Högberg and I co-wrote a paper that was entitled "Heritage Futures and the Futures of Heritage" (Holtorf and Högberg 2013). At that point we had already been thinking about cultural heritage, the historic environment and the future for a few years and had started a collaboration with the Swedish nuclear waste sector about long-term memory.

The notion of 'Heritage Futures' was also used in the context of the University College London (UCL)based research project (2015-2019) that in 2016 assumed this name as the new project title when the Principal Investigator and the Co-Investigators felt that the original name "Assembling Alternative Futures for Heritage" was too unwiedly.

The UNESCO Chair on Heritage Futures used this term from the very first application submitted in December 2015 to the Swedish Research Council, so this grew out of some of the same discussions we were having at that time.

The concept is short and memorable, and it served all of us well. But it is also somewhat difficult to grasp, and many assume we are interested in promoting "the future of heritage and conservation." But this is not actually our primary focus or interest. We do not claim to have any privileged knowledge about the future, whether relating to heritage, conservation or more generally. We are not particularly interested either in ensuring a specific future for heritage or conservation.

In the UNESCO Chair, we say that heritage futures are concerned with the roles of heritage in managing the relations between present and future societies, e.g. through anticipation, planning and prefiguration. That relation between present and future societies is our domain of interest.

As far as our perception of the future is concerned, there are some general trends that are ongoing and well known, e.g. relating to climate change, various demographic shifts, technological developments, and also relating to social tensions and conflicts. These trends are not affected very much by specific unpredictable events such as the corona crisis. They can form the basis for the way we think today about the next few decades, including implications for policy-making.

We think that the most important question of conservation is not how much of the cultural heritage of any one period may or may not survive intact into the future but rather which heritage and historical legacy, which we are going to leave behind, will come to benefit future generations the most. We also believe that as we move into the future, a big challenge of sustainable heritage management is how to allow heritage to absorb changes while continuing to provide benefits for human societies, given the added difficulty that the nature of these benefits may change over time.

TM: Which benefits for human societies would that be? How do you think that civil society can engage in the management of heritage? And what is the importance of future's thinking and future 
literacy for sustainable heritage management?

$\mathrm{CH}$ : Heritage can have many different benefits for human societies, e.g. enhancing health and wellbeing, improving social cohesion and integration, providing collective meaning and purpose, encouraging inspiration and creativity, offering a resource for entrepreneurship and to create employment. We see many examples of such uses of heritage already today. It is important to involve civil society in managing heritage because the expertise and experience required for successful management is bigger than what specialists in the traditional heritage-related disciplines can provide on their own. Heritage must serve the people (not vice versa). To provide extensive benefits for society, the sector needs all the engagement in society it can get.

Futures literacy is the capacity to use our imagination in order to relate present-day realities to multiple possible futures. Futures literacy requires a fair amount of future's thinking, and both are a precondition for competently making heritage management sustainable in the long term. We need to ask what challenges may be most important in the future and endeavour to provide future societies with the best resources we can muster to address these challenges. $A$ heritage that does not benefit future societies is not sustainable. More importantly, a society that cannot solve its biggest challenges is not sustainable either. If we believe that heritage can and should make a contribution to this task we need to develop future's thinking in heritage management in order to increase futures literacy in our sector.

TM: When it comes to the "heritage sector", museums usually play a big role in communicating heritage and "branding" heritage as such (paraphrasing your book [Holtorf, 2008]). In your vision/ experience, how do you see the role of museums engaging in 'Heritage Futures' (or building up future literacy)?

$\mathrm{CH}$ : My book Archaeology is a Brand! is specifically about the brand of the discipline of archaeology, and I have not thought much about whether there are other "brands" of heritage. Museums provide one common format for heritage and heritage futures are therefore relevant in a museum context too. In the Heritage Futures research project one of the four themes we were investigating was focussing on profusion in museum collections (led by Sharon Macdonald). How do we cope with the problem that many collections contain more objects than we can really take care of and perhaps also more than will be able to provide benefits to future generations? Elsewhere, the pedagogical unit at Kalmar County Museum collaborated with our Chair in the development of a time travel role-play to the future. That turned out to be a very powerful pedagogical project which helped increasing participants' futures literacy.

TM: Did both projects of UNESCO and UCL go in different ways? Do they communicate with each other? And how is interdisciplinarity dialoguing between different areas of knowledge, research, education and industry through 'Heritage Futures'?

$\mathrm{CH}$ : There are several direct links between both initiatives, not the least concerning some of the people involved, as there is a considerable overlap. Besides me, even Sarah May and Anders Högberg were directly associated with the Heritage Futures project at $\mathrm{UCL}$, and a similar overlap exists even 
among our collaborators beyond academia.

Heritage futures is a field that is very interdisciplinary, as our work is addressing broad societal challenges and is not defined by specific methods or solutions. We have all learned a lot from working closely with people who were educated in different academic fields and have experience in different sectors of society.

Our work is now being published in two volumes (Harrison et al 2020; Holtorf and Högberg 2020). These two works document many collaborations across disciplines and sectors, exploring heritage futures.

TM: You also have been working recently with the industry sector in Sweden. Can you talk about that experience? How did Heritage Futures bond to the industry sector? How can industrial disposal sites improve heritage management sustainably in the long term?

$\mathrm{CH}$ : We have been collaborating with the nuclear waste sector since 2011 , and this project really was the start of our interest in the future. Everything else followed from that initial engagement. We have learned an awful lot from working in this context, especially from our collaboration with SKB, the Swedish company in charge of managing nuclear wastes and spent fuel from nuclear reactors. What the nuclear waste sector has to offer to the heritage sector is a very thorough and systematic, interdisciplinary and open-minded engagement with questions about the preservation of memory across many generations. What we are offering them is possibly some more subtlety in the way they engage with heritage and society over long time periods. We are now extending our interest to hazardous wastes more generally but it is always related to questions about the preservation of memory.

TM: Following the previous question, how far could 'Contract Archaeology' engage in interacting with these industries? Or how would you advise archaeologists to do so? Especially during economic recession times...

$\mathrm{CH}$ : Any open-minded archaeologist can collaborate with industry. The key is to try to understand your collaborator's needs and consider how you can contribute to addressing these needs.

In my experience of collaborations with partners outside academia, it is not helpful to think that the world primarily requires more knowledge about the past or more preservation of cultural heritage. A lot of other important things can be learned through an engagement with the past and heritage.

Archaeology is a practice that uses many different skills, many of which are not too difficult to learn, that is interesting to many audiences, and that provides many potential benefits to society and to individuals. We should make more of the versatility of our field of competence and experience and put all our skills to use. 
TM: How do you see the Heritage Futures approach spreading to different contexts/countries?

$\mathrm{CH}$ : The idea of 'heritage futures' can be put into practice wherever there is heritage and a perceived need to manage the relations between present and future societies. We try to think globally in our work and seek collaborations with colleagues around the world. Specific futures are often unique to a given context but futures literacy is needed by all to the same extent.

TM: Tourism also plays a major role nowadays in the heritage sector, are there projects involving Heritage Futures in this area? And how could community-based tourism be part of it?

$\mathrm{CH}$ : Many people in the cultural heritage sector worldwide are interested in cultural tourism. Any discussion about the future of heritage always touches on the future of tourism. There are many projects on cultural heritage and cultural tourism, and they usually make assumptions about the future too. To me, one of the most interesting papers in this area is by Catherine Cameron (2010). She asks some larger questions and, most importantly, she does not assume that future tourism will function like contemporary tourism. I also enjoyed David Ross and co-authors' 2017 paper where they suggest that conservation may not always been required for successful heritage tourism.

TM: Covid-19 addressed many questions to heritage specialists, from cleansing of materials until debating the opening exhibitions and collections. In your opinion, how will these changes impact heritage in a near future? And how will lockdown policies impact on cultural heritage?

$\mathrm{CH}$ : The most interesting question for me is how cultural heritage can address some of the challenges for contemporary and future societies that became prominent as a result of the corona crisis. We issued a commentary that contained the following passage:

\begin{abstract}
"In the light of the global spread and impact of the COVID-19 pandemic, it is time to remind ourselves once more of the interdependences between all the people and communities on this planet. We are all part of an interconnected humanity. In recent weeks, we have been reminded that there is a strong need for global solidarity and co-operation. As the virus has spread across the world's societies, many realised the benefits of a speedy global exchange of correct information, of mutual support and solidarity between people to address everybody's needs, and not the least of joint strategies of medical research and the development of a safe vaccine. Over the years and decades to come, we can expect many other kinds of crises when similar collaboration will be important. Maybe it is time to start identifying and promoting a new kind of world heritage that is not employed to bolster national pride and generate financial benefits for a limited group. We might be better served by a world heritage that reaffirms the many interconnections and common interests between all branches and specimen of humanity - and indeed between humans and other living beings on this planet." (from http://blogg.Inu.se/unesco/files/2020/04/Heritage-Futures-CORONA.pdf)
\end{abstract}

The lockdown will create its own cultural heritage and I understand that several museums and other heritage organisations have started collecting already!

TM: And lastly, I would like to ask what is your idea of the future? And how does archaeology relate 
to it?

$\mathrm{CH}$ : There are many different futures, not the least depending on how far you are looking ahead. Generally, I am optimistic for humanity, partly because of the astonishing track record of human development and partly because I believe that home sapiens is very capable of adapting to changing circumstances. I know that there are many people who would challenge both claims but there we are.

Archaeology should become more interested in the future. When people say it is impossible because the future hasn't happened yet and we do not know what it will bring, I hold against that there are many ways in which archaeologists can productively engage with the future. I have recently written two papers along these lines that will hopefully stimulate some discussion on this topic (Holtorf 2020a and 2020b).

As for the future of archaeology, it is not certain that archaeology will continue to exist forever, in fact it is more likely that it won't. After all, it wasn't here from the start of human evolution either. I don't necessarily think that the end of archaeology is very near or that it would be a big problem. There are many other fields that are interesting and worthwhile to pursue, we may not even miss it much.

TM: The notion of 'archaeology' certainly has changed a lot since the antiquarian interests, descriptive-classificatory collections, historical cultural overview on migrations to define culture or 'archaeological culture', then came processualism, post-processualism and new approaches to contemporary archaeology - which we are just in. Maybe it will just change, again. Thank you so much Cornelius for sharing your thoughts and information about Heritage Futures with us. 


\section{REFERENCES}

Cameron, C. (2010). The unnatural history of heritage: what's the future for the past? Journal of Heritage Tourism 5(3), 203-218. Doi:10.1080/1743873X.2010.505289.

Harrison, R., DeSilvey, C., Holtorf, C., Macdonald, S., Bartolini, N., Breithoff, E., Fredheim, H., Lyons, A., May, S., Morgan, J. \& Penrose, S. (2020). Heritage futures: comparative approaches to natural and cultural heritage practices. UCL Press.

Holtorf, C and A. Högberg (2013). "Heritage Futures and the Future of Heritage." In: S. Bergerbrant and S. Sabatini (eds), Counterpoint: Essays in Archaeology and Heritage Studies in Honour of Professor Kristian Kristiansen, pp. 739-746. BAR Int. Ser. 2508. Oxford Archaeopress.

Holtorf, C. (2008). Archaeology is a brand!: The meaning of archaeology in contemporary popular culture. Routledge.

Holtorf, C. (2020a). An archaeology for the future: from developing contract archaeology to imagining post-corona archaeology. Post-Classical Archaeologies. 10, 57-72.

Holtorf, C. (2020b) Heritage Futures, Prefiguration and World Heritage. Forum Kritische Archäologie. 9, 1-5. (with comments by Trinidad Rico, Hilmar Schäfer and Lewis Borck).

Holtorf, C. and Högberg, A. eds (2021) Cultural Heritage and the Future. London and New York: Routledge.

Ross, D., G. Saxena, F. Correia, and P. Deutz. (2017). "Archaeological Tourism: A Creative Approach." Annals of Tourism Research 67: 37-47. doi:10.1016/j.annals.2017.08.001. 